\title{
The Rare Earth Element geochemistry of Mesoproterozoic clastic sedimentary rocks from the Rautgara Formation, Lesser Himalaya: Implications for provenance, mineralogical control and weathering
}

\author{
SA Rashid \\ Department of Geology, AMU, Aligarh - 20200, INDIA \\ For correspondence, E-mail: rashidamu@hotmail.com
}

The geochemical studies of clastic sedimentary rocks have attracted attention of several scientistsin the world primarily to understand their source rock compositions, paleoclimatic conditions, tectonic setting and in turn to examine the nature and composition of the upper crust through time (Bhatia 1985, Taylor and McLennan 1985, Condie1993, McLennan etal. 2000). Damta Group (consisting of Chakrata Fm and Rautgara Fm) which is considered to be the oldest and best-preserved supracrustal pelite-quartzitesuccessions in theinner carbonate belt of the Lesser Himalaya (Valdiya 1998) is best suited for this kind of studies. The Mesoproterozoic clastic sedimentary rocks, comprising pelites and quartzites from the Rautgara Formation in and around Rudraprayag, Garhwal region, Uttaranchal, Lesser Himalaya, have been analysed for major and trace elements including Rare Earth Elements (REEs) to evaluate their provenanceand weathering history. Exceptfew studies(Bhatand Ghosh 2001, Rashid 2002) the sedimentary geochemistry is almost unattended in theHimalayas despitetheir occurrenceas most abundant rock type. In this context any work from the Himalaya may be considered as a significant contribution towards understanding the Precambrian upper crustal composition in theHimalayan region.

The pelitic rocks from the Rautgara Fm are characterised by moderate $\mathrm{SiO}_{2}$ and $\mathrm{Al}_{2} \mathrm{O}_{3}$ contents and show consistent REE patterns with LREE (light REE) enriched and HREE (heavy REE) depleted patterns $\left(\mathrm{La}_{\mathrm{N}} / \mathrm{Yb}_{\mathrm{N}}=7.4-10.3\right)$. Thetotal REE abundances are high (up to $266 \mathrm{ppm}$ ) with large negative Eu-anomalies $\left(\mathrm{Eu} / \mathrm{Eu}^{*}=0.57\right.$ to 0.64$)$. The REE characteristics of the Rautgara pelites compare very well with the average post-Archean REE patterns of European Shales (ES), Post Archean Shales from Australia (PAAS) and North American Shale Composite (NASC). Except high $\mathrm{SiO}_{2}$ contents, the other major and trace element concentrations aresignificantly low in theassociated quartzites. Although the quartzites contain low REE abundances (up to 41 $\mathrm{ppm}$ ) their patterns including negative Eu anomalies are akin to pelites, suggesting that both the rock types be derived from similar source. The Chemical Index of Alteration (CIA) and A-CNK plot (NesbittandYoung 1984) indicates that moderatechemical weathering has taken place in the source region of the Rautgara rocks. The linear correlation coefficients between $\mathrm{Al}_{2} \mathrm{O}_{3}, \mathrm{~K}_{2} \mathrm{O}, \mathrm{TiO}_{2}$ and total REE reveal that the accessory minerals (mainly Tibearing phases) have hosted the REEs (Taylor and McLennan 1985, Condie 1993).

Theevolved felsic composition of therocks probably related to widespread acidic igneous activity in the source. Besides the provenance, the sedimentary REE patterns seem to have been affected by sedimentary environment also. The paleocurrent studies in thearea (Valdiya 1998) indicatethat thegranitoid rocks from the Aravalli mountain belt and Bundelkhand massif have supplied detritus to the Lesser Himalayan Rautgara sedimentary basin.

\section{References}

Bhat MI and SK Ghosh. 2001. Geochemistry of the 2.51 Ga old Rampur group pelites, western Himalayas: implications for their provenance and weathering. Precambrian Research 108: 1-16

Bhatia MR. 1985. Rare earth element geochemistry of Australian Paleozoic graywackes and mudrocks: Provenance and tectonic control. Sedimentary Geology 45: 97-113

Condie KC. 1993. Chemical composition and evolution of the upper continental crust: contrasting resultsfrom surfacesamples and shales. Chemical Geology 104: 1-37

McLennan SM, A Simonetti and SL Goldstein. 2000. Nd and Pb isotopic evidence for provenance and post-depositional alteration of the Paleoproterozoic Huronian Supergroup, Canada. Precambrian Research 102: 263-278

Nesbitt HW and GM Young. 1984. Prediction of some weathering trends of plutonic and volcanic rocks based on thermodynamics and kinetic considerations. Geochim et Cosmochim Acta 48: 1523-1534

Rashid SA. 2002. Geochemical Characteristics of Mesoproterozoic Clastic Sedimentary rocks from the Chakrata Formation, Lesser Himalaya: implications for crustal evolution and weathering history in the Himalaya. Journal of Asian Earth Sciences 21: 285-295

Taylor SR and SM McLennan. 1985. The continental crust: its composition and Evolution. Blackwell, Oxford

Valdiya KS. 1998. Dynamic Himalaya. Universities Press, Hyderabad 